\title{
Brunei Teachers' Perspectives on Questioning: Investigating the Opportunities to "Talk" in Mathematics Lessons
}

\author{
Masitah Shahrill ${ }^{1} \&$ David J. Clarke ${ }^{2}$ \\ ${ }^{1}$ Sultan Hassanal Bolkiah Institute of Education, Universiti Brunei Darussalam, Bandar Seri Begawan, Brunei \\ Darussalam \\ ${ }^{2}$ International Centre for Classroom Research, Melbourne Graduate School of Education, The University of \\ Melbourne, Carlton, Victoria, Australia \\ Correspondence: Masitah Shahrill, Sultan Hassanal Bolkiah Institute of Education, Universiti Brunei Darussalam, \\ Jalan Tungku Link, Gadong, BE 1410, Bandar Seri Begawan, Brunei Darussalam. Tel: 673-246-3001. E-mail: \\ masitah.shahrill@ubd.edu.bn
}

Received: April 3, 2014 Accepted: May 16, 2014 Online Published: June 17, 2014

doi:10.5539/ies.v7n7p1 URL: http://dx.doi.org/10.5539/ies.v7n7p1

\begin{abstract}
A teachers' practice cannot be characterised by a single lesson, hence comparison is best made with lesson sequences that better sample the diversity of a teacher's practice. In this study, we video recorded lesson sequences in four Year 8 mathematics classrooms, as well as interviewed each of the four teachers in Brunei Darussalam. Because of our methodology and based on the findings from the richness in the data that was collected, there were some features in the video and interview data that emerged. One of the features is the significant short utterances made by the students as well as their respective teachers, and the extent of the teachers' own and their students' questioning behaviours in the lessons as perceived by the teachers themselves during the video-stimulated recall interviews. In the four Brunei classrooms that we studied, most of the lessons were so rushed, the teachers did most of the talking and when teachers and students do interact, it almost always involved faster-paced exchanges between them. Thus, restricting students to single words ("yes" or "no") or short choral responses. Overall, the findings appear to indicate that short utterances implied that there were less (or even no) opportunities for fuller student participation in classroom discussions.
\end{abstract}

Keywords: choral responses, utterances, talk, questioning, secondary mathematics, video-stimulated recall interviews, Brunei Darussalam

\section{Introduction}

In the field of mathematics education, although untangling the relationship between teaching and learning is not easy and may pose many unexpected complications (Ball, 2002; Floden, 2001; Franke, Kazemi, \& Battey, 2007; Goos, Stillman, \& Vale, 2007; Hiebert \& Grouws, 2007), the underlying reason why we do research on the teaching and learning of mathematics is because "we want to know why students do not get enough out of their mathematical education, and what we can do to remedy the situation" (Niss, 2007, p. 1293). In researching classrooms, it is predictably difficult to conduct investigations, carry out the analyses and report on the findings on both the teacher and the students at the same time. Hence, the reasons why research reports frequently address only the teacher or the students.

In researching students' needs, Franke and her colleagues focused on three different yet critical features of mathematics classroom practice: discourse, norms and building relationships, because they argued that "consensus is building that students need opportunities in classrooms to share their mathematical thinking, discuss alternative approaches to solve problems, use mathematical tools flexibly, and so on" (Franke, Kazemi, $\&$ Battey, 2007, p. 248). They further stated that these three features are interlinked and advances in research conducted surrounding these critical features may help us to understand the unfolding nature of how students learn and what benefits they may acquire from their experiences, of doing and learning mathematics, in classrooms.

In Brunei for example, a study by Mundia (2010a) found that repeating a mathematics class was not highly therapeutic or beneficial in that most of the repeaters still failed mathematics. The main reason for this problem 
here is because the failing students are not properly diagnosed to identify their real support needs which require to be addressed in the repeated year's teaching (see Sarwadi \& Shahrill, 2014). Often it is students that held misconceptions (Ang \& Shahrill, 2014; Shahrill, 2005, 2011, 2013b) and students with learning disabilities (particularly those with intellectual difficulties) who do not perform well in mathematics. Although the implementation of inclusive education was partly intended to address the problems of this category of learners, much still remains to be done to help improve the teachers' skills and self-efficacy in dealing with learners with high support needs (see Mundia, 2009; Tait \& Mundia, 2014). For instance, there is need to increase teachers' awareness and sensitization about helping learners with high support needs (Haq \& Mundia, 2012). It is important for teachers as well to assist in molding the correct conceptions of learning held by students from the early stages in their schooling so that meaningful learning can be achieved (Jaidin, 2009). Student-teachers who studied at the local university were also aspired to be reflective practioners of their own practices in their classroom teaching (Jawawi, 2009, 2010). Under the ongoing curriculum reforms known as the National Education System for the $21^{\text {st }}$ Century or SPN21 (Sistem Pendidikan Negara Abad Ke-21, in Bahasa Melayu language), teachers in Brunei government schools are supposed to be more proactive, resourceful and adaptive in helping less-able students. Student evaluations were also innovated with the introduction of school-based assessment and assessment for learning to support the new curriculum (Mundia, 2010b; Nor \& Shahrill, 2014). These two major changes in school curriculum and student assessment, prompted the reform of teacher education in Brunei which began in 2009 and continues today (Mundia, 2012a; Tait \& Mundia, 2013). The Ministry of Education in the Government of Brunei has also recently designated five model schools to serve as examples of effective teaching (including questioning) to teachers (see Omar et al., 2014).

On the other hand, the attention of much of the research studies around the world has turned to teachers and their teaching in mathematics classrooms. It has been reported that teachers do make a difference in students' learning (Goos, Stillman, \& Vale, 2007; Hiebert et al., 2003). According to Anna Sfard's plenary report at the $10^{\text {th }}$ International Congress on Mathematical Education (ICME) presented in Copenhagen in July 2004 (and later published in Sfard, 2005),

...the last few years have been the era of the teacher as the almost uncontested focus of researchers' attention. This is quite a change with respect to the last two decades of the 20th century which were almost exclusively the era of the learner. And we have certainly come a long way since the era of the curriculum, roughly corresponding to the 1960s and 1970s when the main players in the educational game were the developer and the textbook (Sfard, 2005, p. 409).

The statement above visibly echoed in Philipp's statement on his review of the literature on teachers' beliefs and affect for the second handbook of research on mathematics teaching and learning, "To understand students' experiences with school mathematics, one must understand a central factor in their experience: mathematics teachers" (Philipp, 2007, p. 257). How teachers teach and the teaching processes within the classroom have become the primary focus of researchers around the globe in investigating mathematics classrooms.

Moreover, the advent of video recording of classroom lessons has opened up new possibilities for research studies in classroom teaching and learning (Ainley, 2007). Video-based studies are expected to have the greatest potential to inform the classroom practices of any teachers because of its ability to sustain and its capacity to capture the complexities of a classroom, and subsequently, conduct varieties of multiple analyses of classroom teaching by connecting classroom practices and consequent learning from multitude of different perspectives (Clarke, 2003; Fitzgerald, Hackling, \& Dawson, 2013).

The data collection approach in our study adapted the Learner's Perspective Study (LPS) approach. The LPS is a classroom study of video recorded lessons. However, the approaches used in the LPS project are quite different from other approaches to classroom research because of their "Complementary Accounts Methodology" (see Clarke, 2001). The project involves videotaping a considerable number of consecutive lessons or a sequence of lessons, rather than just single lessons, for each participating teacher. The participating teachers were regarded as "competent" or "highly-effective" teachers based on their selection by their "local" mathematics education community (Clarke, 2004, 2006a, 2006b; Clarke, Emanuelsson et al., 2006; Clarke, Keitel, \& Shimizu, 2006; Clarke, Mesiti et al., 2006; Clarke et al., 2007; Clarke \& Xu, 2007, 2008; Koizumi, 2013).

In the LPS data collection approach, the research team collected sequences of 10 lessons from three 'well-taught' Grade 8 mathematics classrooms using a three-camera approach: Teacher camera, Student camera and Whole Class camera. Note that in the context of the LPS project, Clarke, Emanuelsson et al. (2006) explained 
"well-taught" as "...the teachers in each country were recruited according to local criteria for competence: visibility as presenters at conferences for other teachers, leadership roles in professional organisations, and, acclamation by colleagues and students" (pp. 8-9). In addition to the three video camera approach, the teacher and the focus students were interviewed using the video footage of their lessons as stimulus for their reconstructions of classroom events, a process also known as post-lesson video-stimulated recall.

\section{International Perspectives on Questioning and Classroom Interactions}

Questioning can be one of ways in generating the kind of talk and communication that can lead to learning. Many educators use questions and answers as an instructional strategy. However, the benefits in this teaching method requires the users (both teachers and students) to demonstrate clarity of expression and effective exposition of points (Chong \& Shahrill, 2014; Shahrill, 2013a, 2013c; Shahrill \& Mundia, 2014). Using questions as part of a tool in teaching is a good strategy that can motivate and challenge students' thinking and learning processes that may eventually lead to classroom interaction. Additionally, previous research shows that the students' asking of questions might generally be regarded as "a useful process in their pursuit of learning in that questioning is one of the most important ways students can support their own learning to become literate, well-educated people" (Boaler \& Humphreys, 2005, p. 72). To be effective, however, the questions used (both oral and written) should be stated or phrased in a simple and friendly manner. Evidence from research on learning styles and study strategies of students from a developing country who speak English as a second language demonstrates the significance of using language properly in exposition and questioning (Shahrill, Matzin, Mahalle, Hamid, \& Mundia, 2013). Shahrill and colleagues found that the successful students in mathematics depended largely on language-based expressive learning styles and study strategies such as speaking, writing, and reading. This implied that questions that are hard, tricky or confusing were likely to lower students' interest and motivation to learn and this was more evident in young learners (Mundia, 2007, 2012b).

There are two comparative studies on teachers' questioning from video lessons. Each study used specifically the data available from the TIMSS 1995 video study and the LPS project. Kawanaka and Stigler (1999) investigated teachers' use of questions in eighth-grade mathematics classrooms in Germany, Japan and the United States. They explored the patterns of discourse by focusing on teachers and students talk during lessons as well as the teachers' use of higher order questions in the classrooms. Initially, they recorded a total of 231 lessons, 100 German, 50 Japanese and 81 US lessons, ans subsequently 30 randomly selected video recorded lessons from each country were analysed. However from their analyses, not all the 30 lessons contained higher order questions they categorised as requesting descriptions or explanations. Lessons that had them portrayed teachers in the three countries asked different kinds of higher order questions related to lesson activities that occurred at particular times during particular events in the lessons. Meanwhile, Koizumi's (2013) study was part of the LPS project that explored the similarities and differences in teachers' questioning from German and Japanese mathematics classrooms by specifically focusing at the stage of introducing new mathematical content. Based on Koizumi's findings, the role of questions that previous studies regarded as lower cognitive questions, such as recalling previously learned material, was seen as important especially at the stage of introducing new content materials. Since the lessons recorded were sequences of consecutive lessons, Koizumi also found patterns in the teachers' questioning that repeatedly emerged from connecting the previous to the subsequent lessons. Both comparative studies mentioned above analysed their data using video recorded lessons although the approach in collecting the data was distinctively different.

\subsection{Studies of East Asian Classrooms}

There has been increasing attention given to the study of mathematics classrooms in East Asian countries, ever since East Asian students outperformed their Western counterparts in international comparative studies in mathematics achievement (Leung, 2001; Park \& Leung, 2006). The attention then turned to East Asian classroom instruction to investigate whether their instructional practices might have contributed to the students' academic success. However, prior studies of East Asian classrooms had noted that, as a general norm, practices found in East Asian mathematics classrooms were content-oriented and examination-driven, involving very traditional and old fashioned teaching, teacher-centred instruction, minimal student involvement, learning by rote or passive learning, and employing procedural teaching strategies (Biggs, 1994; Leung, 1995, 2001, 2005, 2006, 2008a, 2008b; Lim, 2007; Park \& Leung, 2006; Zhang, Wong, \& Leung, 1998).

In a different study drawing from the LPS classroom study of video recorded lessons mentioned above, Clarke and colleagues focused in adopting the discursive practices in the mathematics classrooms. They found considerable variance in students' opportunities to hear and speak mathematics in the public segments of their lessons, between countries identified as "Asian" (Hong Kong, Shanghai, Tokyo, Singapore and Seoul) and those 
as "Western" (Melbourne, Berlin and San Diego) (Clarke et al., 2013b). Furthermore, these researchers have also found a connection between classroom mathematical orality and student learning outcomes where they claimed, that "those classrooms that promote student spoken use of mathematical terms do develop in those students the capability to use mathematical terms to describe their mathematics classroom and their mathematics learning" (Clarke et al., 2013c, p. 50).

Leung (2005) analysed the East Asian mathematics classrooms (Hong Kong and Japan) in the TIMSS-99 Video Study, and based on his analysis he identified several distinctive features of the classrooms in those two East Asian countries, for example, the East Asian classroom is teacher-dominated (with a lot of teacher public talk), and their students were the least talkative in the study (Note 1). In relation to this particular feature, Leung argued that despite the stereotype that many people have of East Asian classroom, the findings of the TIMSS-99 Video Study revealed that meaningful learning can still take place in teacher-directed classrooms. Furthermore, he made a powerful statement in regard to how students might benefit from their teachers' actions.

Teacher dominance with a lot of teacher talk does not necessarily lead to passive, receptive learning. Much depends on the content of the teacher talk and how it is delivered, and whether the talk can stimulate students to be engaged in the mathematics. Indeed, from the data obtained in this study, it seems that the kind of teacher talk in the East Asian classroom was able to direct students to be engaged in the lesson (Leung, 2005, pp. 209-210).

Leung (2005) concluded his analysis by stating that the East Asian classroom practices investigated in the TIMSS-99 Video Study are "deeply rooted in the underlying cultural values of the classroom and the wider society" (p. 212). These are interesting fndings because Brunei does not seem to fall within the so-called Confucian-heritage cultures (CHC), the dominant culture in East Asia. According to Biggs (1994), CHC countries are Mainland China, Taiwan, Singapore, Hong Kong, Japan and Korea. The Brunei population is just over 417, 000 (July 2013 est.) and comprised mostly of Malay (66\%), with $11 \%$ Chinese, and other races such as Indians, indigenous ethnic groups and expatriates making up the rest of the country's population. Although Brunei has a predominantly Malay culture, it appears from earlier studies and anecdotally that the reality of mathematics teaching and learning in the Brunei classrooms is similar to those of the $\mathrm{CHC}$ countries. If indeed this were the case, then would Brunei perhaps show similar features to those of Hong Kong and Japan, the representative East Asian "high-achieving" countries in the TIMSS-99 Video Study?

The findings reported in this paper represented only a small part of a larger study conducted by the first author where she identified the similarities and differences between Brunei Darussalam and the countries that participated in the TIMSS-99 Video Study (see Shahrill, 2009).To date, most studies done in Brunei concentrated mainly on the specific mathematical content that focused on upper secondary mathematics classrooms, each from a different secondary school in Brunei Darusslam (such as Go \& Shahrill, 2014; Khoo, 2001; Lim, 2000).A recent study examining the classroom interactions in three Year 10 upper secondary mathematics classrooms in Brunei Darussalam were conducted and reported. The results of the study revealed that majority of the lesson time for all three classes were spent on public interaction (78.9\%) rather than private interaction (10.4\%). Moreover, it was found that the types of interaction have no direct effect on the students' learning; rather it was how the teacher portrayed these types of interaction that can affect the students' learning (Salam, 2011; Salam \& Shahrill, 2014).However, lacking from all these research studies conducted in Bruneiare teachers' perspectives on their own and their students' questioning behaviour.

\section{Objectives of the Study}

The purpose of this study was to examine firstly, how often the teachers and the students talk during the public interaction segments, and secondly, to elicit any emerging issues from the teachers' perspectives on their students questioning behaviour (students-to-teacher) as well as the teachers' perspectives on their own questioning actions (teacher-to-students) in the mathematics lessons that were video recorded.

\section{Method}

As a reminder, the data collection approach in this study adapted the LPS approach mentioned above.

\subsection{Sample}

The two secondary schools that participated in this study were based on convenience sampling. The recruitment of the four Brunei teachers was based on the nomination and recommendation of the Principals in their 
respective schools. These teachers were recognised by their Principals and their peers to be competent at teaching mathematics at the Year 8 level. In School 1, in addition to the nomination of their two teachers, the Principal and the Deputy Principal also recommended the classes that those teachers were teaching. While in School 2, it was the teachers themselves who nominated their choice of class to be filmed. The teachers in School 1 are both male (Hamzah and Amir), while in School 2, both the teachers are female (Yasmin and Masnah). Hamzah, Yasmin and Masnah are considered early career teachers with two years of teaching experience, at the time of study. Amir however had six years of teaching experience. Note that the teachers' names reported here are pseudonyms.

\subsection{The Data Collection Approach in this Study}

Due to the resource limitations, only two video cameras were used in this study; one camera (the Teacher Camera) was directed solely at the teacher throughout the lesson, while the other camera (the Student Camera) was stationary, positioned near the front of the room with the purpose of maintaining a wide-angle shot of the whole class. The teacher's utterances were recorded using a radio wireless microphone attached to the teacher and transmitted to the Teacher Camera. Interviews by the first author with each of the four Brunei teachers were conducted after all their lessons had been observed and video recorded. A quiet meeting room (for the School 1 teachers) and an empty classroom (for the School 2 teachers) were chosen to conduct the interviews. The equipment used during the interview was a video camera that was connected to a television and another video camera to record the interview process. The interviews were conducted in both the English and Malay Languages, and later transcribed.

At the beginning of an interview, the teacher was asked to pick one lesson from his/her video recorded lesson sequence. Note that if the lesson picked was a single period lesson (a lesson of 30 minutes), the teacher was asked to pick an additional lesson to discuss in the interview. The recorded tape of the chosen lesson was then loaded into the video camera and the video footage was ready to be watched from the television monitor. The interviews involved video-stimulated recall (c.f. Clarke, 2006a), and the teacher had the remote control. $\mathrm{He} / \mathrm{she}$ was able to view parts of the video recorded lesson and press pause to stop the recorded tape whenever he/she wished to comment on events in the classroom that he/she considered important. All the interviews were video recorded with the exception of two teachers in School 2. Upon their request, only their voices and the television monitor showing the lesson(s) that they picked were recorded.

By adapting the LPS project data collection methods, using videos from both the Teacher and Student Cameras, not only were we able to capture the teachers' presentation of the mathematical content and also their execution of teaching practices, we were also able to capture important classroom events and interactions between a teacher and his/her students, and amongst the students themselves (Shahrill, 2009). In other words, by using two video cameras, we were able to film events from two perspectives simultaneously (DuFon, 2002). Another aspect was the video-stimulated recall interviews with each of the Brunei teachers. From the interviews, by watching the video recorded lesson (chosen by the teachers), the teachers were then able to provide useful insights by effectively recalling any associated feelings or thoughts in relation to the events in his/her classrooms (Clarke, 2001, 2006a).

Table 1 displays the number of video recorded lessons that were recorded consecutively for each Brunei teacher, and the variety of topics covered by them during the video recorded period.

Table 1. Frequency of the video recorded Brunei mathematics lessons $(N=20)$ including the topics covered

\begin{tabular}{cccl}
\hline School & Teachers & $\begin{array}{c}\text { No. of video } \\
\text { recorded lessons }\end{array}$ & \multicolumn{1}{c}{ Topic(s) } \\
\hline 1 & Hamzah & 5 & $\begin{array}{l}\text { Algebraic Expressions and Formulae, Circles, Introduction to } \\
\text { Statistics and Transformation } \\
\text { Andices and Introduction to Statistics }\end{array}$ \\
2 & Yasmin & 4 & $\begin{array}{l}\text { Introduction to Statistics, and Revision on Mathematics Paper 1: } \\
\text { Whole Numbers, Fractions, Decimals, Integers, Approximation } \\
\text { and Estimation, Algebra, Rate, Ratio and Proportion, Perimeter } \\
\text { and Area, and Surface Area and Volume }\end{array}$ \\
\hline
\end{tabular}




\subsection{Data Analysis}

Before presenting the results in the following section, we need to provide the definitions for public interaction and public utterances. According to Hiebert et al. (2003), public interaction is defined as "public presentation by the teacher or one or more students intended for all students" (p. 53) and a public utterance is defined as talk (during the public interaction segment) by one speaker uninterrupted by another speaker (Hiebert et al., 2003). Therefore, the opportunity for the teachers and students to talk, as indicated by the length of each their utterances, is taken during the public interaction segments of the video recorded Brunei lessons. Furthermore, there were several complications encountered whilst analysing the utterances in the collected data. First of all, because of time constraints, a research assistant who is fluent in both the Malay and English languages was employed to carry out the analysis. Secondly, because there were no transcripts available for any of the Brunei video recorded lessons, the research assistant had to rely only by watching and listening from the video recorded lessons in order to manually count the number of teacher and student utterances during the public interaction segments in all the Brunei mathematics lessons. Additionally, any public talk in the video data that was spoken in Malay was translated to English.

In counting the Teacher Utterances (TU) and Student Utterances (SU), we divided the segments into short utterances $(1,2,3$, or 4 words in length), and longer utterances $(5+$ and $10+$ words for students, and $5+$ and $25+$ for teachers). Subsequently, we calculated the average percentage of teacher and student utterances of each length per Year 8 mathematics lesson, for each classroom studied and tabulated them in Table 2 below.For each classroom, the average percentage was calculated as the sum of the percentage within each lesson, divided by the number of lessons. To understand the results presented in Table 2 below, it is important to note that the percentages across TU and SU for each classroom in Table 2 do not add up to $100 \%$ because the $25+$ words TU is a subset of $5+$ words TU, and the $10+$ words $\mathrm{SU}$ is a subset of 5+ words SU. In addition, the percentages of 1-4 word teacher (and student) utterances and 5+ word teacher (and student) utterances may not sum to 100 because of rounding. It should also be noted that the results in Table 2 do not give the percentage of teacher and student utterances of the whole class utterances.

\section{Results}

\subsection{Opportunities to Talk in the Mathematics Lessons}

Based on the average percentages of teacher and student utterances in each classroom studied in Brunei (in Table 2 below), the results show that the female teachers (Yasmin and Masnah) made utterances of between 5 to 24 words more often than their male counterparts (Hamzah and Amir), during the public interaction segments of their lessons. What is unusual about the results presented below was the limited use of longer utterances (25+ words for teachers and greater than 5 words for students) in the four Brunei classrooms. And according to these results, not only do the teachers seemed to prefer the use of short public statements in their mathematics classrooms, their students also showed this similar pattern. Furthermore, based on our analysis, the relative proportion of teacher and student utterances of the whole class utterances is $52 \%$ and $48 \%$ respectively. This indicates that the teachers and students made equal opportunities of utterances during the public interaction segments of their lessons.

Table 2. Average percentage of teacher and student utterances

\begin{tabular}{lcccccc}
\hline \multirow{2}{*}{ Teachers' } & \multicolumn{3}{c}{ Teacher Utterances (TU) } & \multicolumn{3}{c}{ Student Utterances (SU) } \\
\cline { 2 - 7 } Classrooms & $1-4$ word & $5+$ word & $25+$ word & $1-4$ word & $5+$ word & $10+$ word \\
& $\mathrm{TU}$ & $\mathrm{TU}$ & $\mathrm{TU}^{1}$ & $\mathrm{SU}$ & $\mathrm{SU}$ & $\mathrm{SU}^{2}$ \\
\hline Hamzah & 52 & 48 & 6 & 93 & 7 & 1 \\
Amir & 43 & 57 & 8 & 92 & 8 & 2 \\
Yasmin & 20 & 80 & 13 & 96 & 4 & 1 \\
Masnah & 34 & 66 & 13 & 94 & 6 & 3 \\
\hline
\end{tabular}

\footnotetext{
${ }^{1}$ Percentage of teacher utterances that were $25+$ words is a subset of teacher utterances that were $5+$ words.

${ }^{2}$ Percentage of student utterances that were $10+$ words is a subset of student utterances that were $5+$ words.
}

From the results given in Table 2, all four teachers and their students had a similarly high frequency of short 
public statements. From our observations of the video data, during the public interaction segments of the mathematics lessons; students were busy copying the notes written on the whiteboard whilst the teacher was discussing or explaining to the whole class, the teachers were not dialoguing with the students, the students were passive, the teachers did most of the talking in the classroom, when the teachers did ask students mathematical questions or whether students understood the topic (that was given in the video recorded lessons), the students typically gave chorused answers (of a few words) or a short reply of "yes" or "no", and in many cases, teacher questions were almost always rhetorical. Even though the four teachers talked (publicly) more in the classrooms, from the collective results of the four Brunei teachers we have shown so far, demonstrated that they were mainly less than 25 words.

From the interview data, only Yasmin acknowledged the fact that she talked a lot in her classroom (including the private interaction segments of her lessons), and this is evidenced in the outcome of her " $5+$ teacher utterances" result $(80 \%$ in Table 2$)$ of the public interaction segments. An example is illustrated in the following excerpt of her interview.

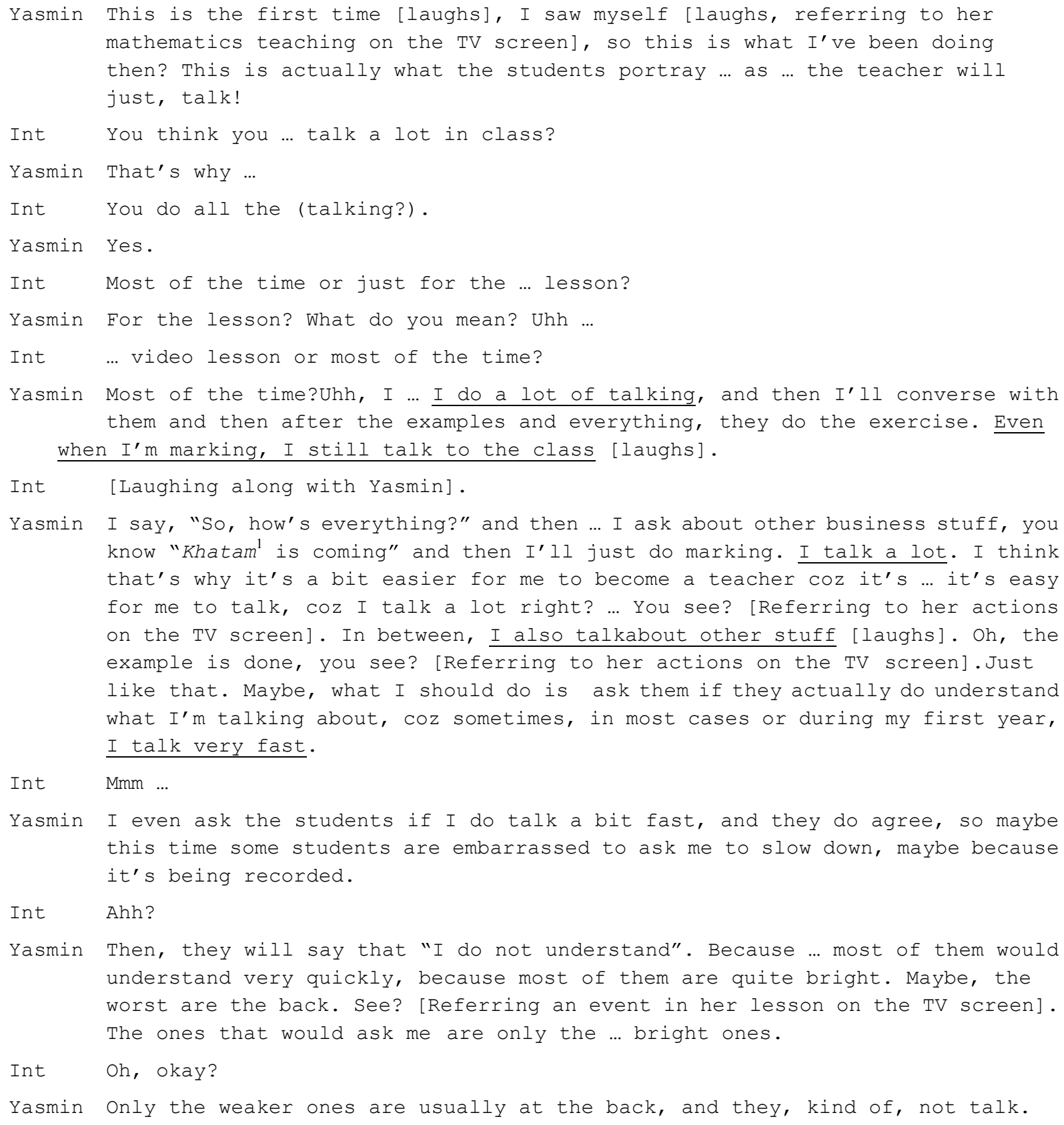

Note: ${ }^{1}$ Khatam is a ceremony to celebrate a Muslim who completed reading/reciting the Qur'an. 
Yasmin has the most number of medium length sentences and based on the transcript above, she claimed that she talked about other things frequently in the classroom. From her video recorded lessons, we also observed that eventhough she encouraged student participation, her questions were mostly rhetorical. Her students seldom got a chance to respond. Unlike the other teachers in this study, she was rather "generous" during her revision lessons. For example, she worked through the solutions (on the whiteboard) for almost all of the revision questions with her students and explained each step to them. In other words, independent student learning was almost non-existent.

Our observations of the students' public talk in each of the four Brunei classrooms is consistent with Hiebert et al. (2003) depiction of short student utterances whereby they reported that "...short utterances often reflect faster-paced "back and forth" exchanges between teachers and students. In faster-paced exchanges, students are typically restricted to single words or short phrases" (Hiebert et al., 2003, p. 110). From the results given in Table 2, student short utterances were consistently high across all four Brunei classrooms. It would appear that these findings together with our observations of the video data are consistent with earlier findings on the pace of curriculum delivery (Shahrill, 2009). In these four Brunei classrooms that we studied, the lessons were so rushed (except for Amir's lessons), the teachers did most of the talking and when teachers and students do interact, it almost always involved faster-paced exchanges between them. Thus, restricting students to single words ("yes" or "no") or short choral responses.

What doesn't make sense is that Amir's lessons were not rushed but the practices we observed in his classroom in relation to the teacher's and students' opportunities to talk (publicly) were the same as the other three classrooms. While Amir stated in his interview that he valued explanations apparently to a much greater extent than the other teachers, however the results showed similar frequencies as the other three teachers with regard to short teacher and student public utterances. Referring to Amir's classroom public-talk transcript, he enjoyed interacting with his students by trying to get several responses from them. And according to the definition given in the TIMSS 1999 Video Study report, “.... an utterance was defined as talk by one speaker uninterrupted by another speaker... Transcribers were instructed to identify a new utterance any time a new speaker began talking, and to note who was speaking (e.g., teacher or student)" (Hiebert et al., 2003, p. 110). Perhaps, because of Amir's preference to (publicly) interact with his students, this might have somehow restricted the number of words of each utterance that Amir made within the public segments of his lessons.

Since longer student utterances were almost completely lacking in the data collected, could this indicate that there were less (or even no) opportunities for fuller student participation in classroom discussions? There are several hypotheses for the Brunei students' lack of participation in the public interaction segments of the mathematics lessons.

- Because some lessons were so rushed, the teacher questions were sometimes rhetorical and this may have hindered or discouraged students to give a response or even participate in the classroom public discussion.

- More than half of the video recorded lessons were single period (30 minutes or less), students may not have been encouraged to participate in any classroom public discussion because they were busy copying the notes or worked solutions on the whiteboard within a limited lesson period.

- $\quad$ Since public interaction segments were reserved for "Public presentation by the teacher or one or more students intended for all students" (Hiebert et al., 2003, p. 53), some students may want to wait until the teacher goes around the classroom (during the private interaction segments) to ask the teacher a question, rather than participate publicly.

- Depending on the personality of individual students, not all of them may be sufficiently brave to voice out a response or a question to the teacher during the public interaction segments.

- Some students may be silently absorbing all that was publicly discussed in the classroom without them showing any interactions/emotions/expressions. These students may be referred to as the 'silent participants' (see Remedios, Clarke, \& Hawthorne, 2008).

- Because of having outsiders and video cameras in the classroom, the students may have been shy and less responsive (not in the case of Amir's students).

- The filming, conducted during the fasting month of Ramadhan may have caused the students to be less active (from lack of energy) than usual.

- The students' reluctance to speak may be culturally related, similar to those suggested by Leung (2005) and other researchers on the $\mathrm{CHC}$ phenomenon. 


\subsection{Teachers' Perspectives on Questioning}

Because of our methodology where we interviewed each of the four teachers at the end of their video recorded lessons, we were able to analyse the teachers' perspectives using their verbal commentaries on the lesson videos that the teachers and the first author watched together as well as from the interview questions. The first question posed to each teacher was "How often do your students ask you questions during the lesson?"

According to the interview data, the responses the teachers gave in regard to the question above were: for Hamzah and Amir "Quite often and the students were not shy" and for Masnah "Every time" (indicating that her students would always ask her a question during the lesson). Hamzah made a further comment regarding how his students overcame their shyness and subsequently being brave enough to ask questions in his mathematics lessons; (he commented) from the start of the school year, he tried starting off as being friendly, making jokes, so as to ease the tension between the teacher and the students. For Yasmin however, the first author failed to ask this particular question during her interview, and instead asked her the following question.

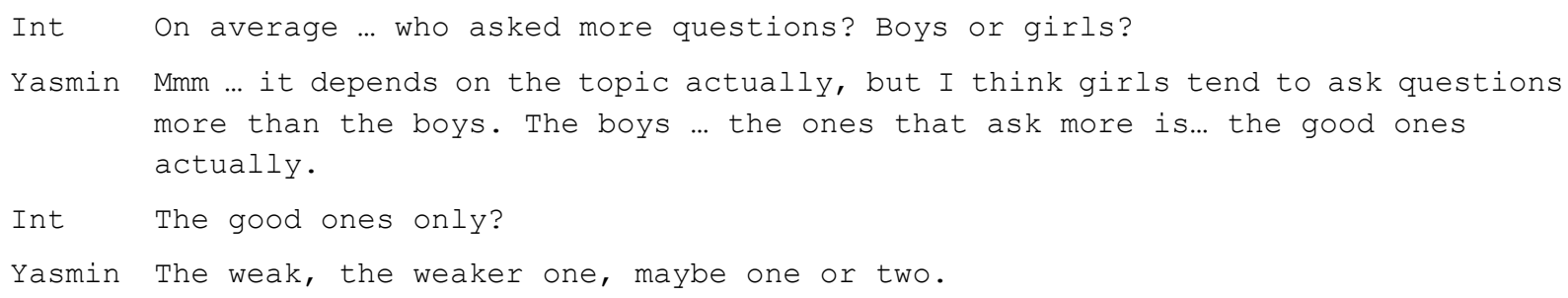

Based on their responses to the question above, the first author then proceeded to ask the teachers what their student(s) typically did in order to ask the question(s), and subsequently, how the teachers attended to their students' questioning behaviour. Provided below are the responses given by the four teachers in relation to these subsequent interview questions.

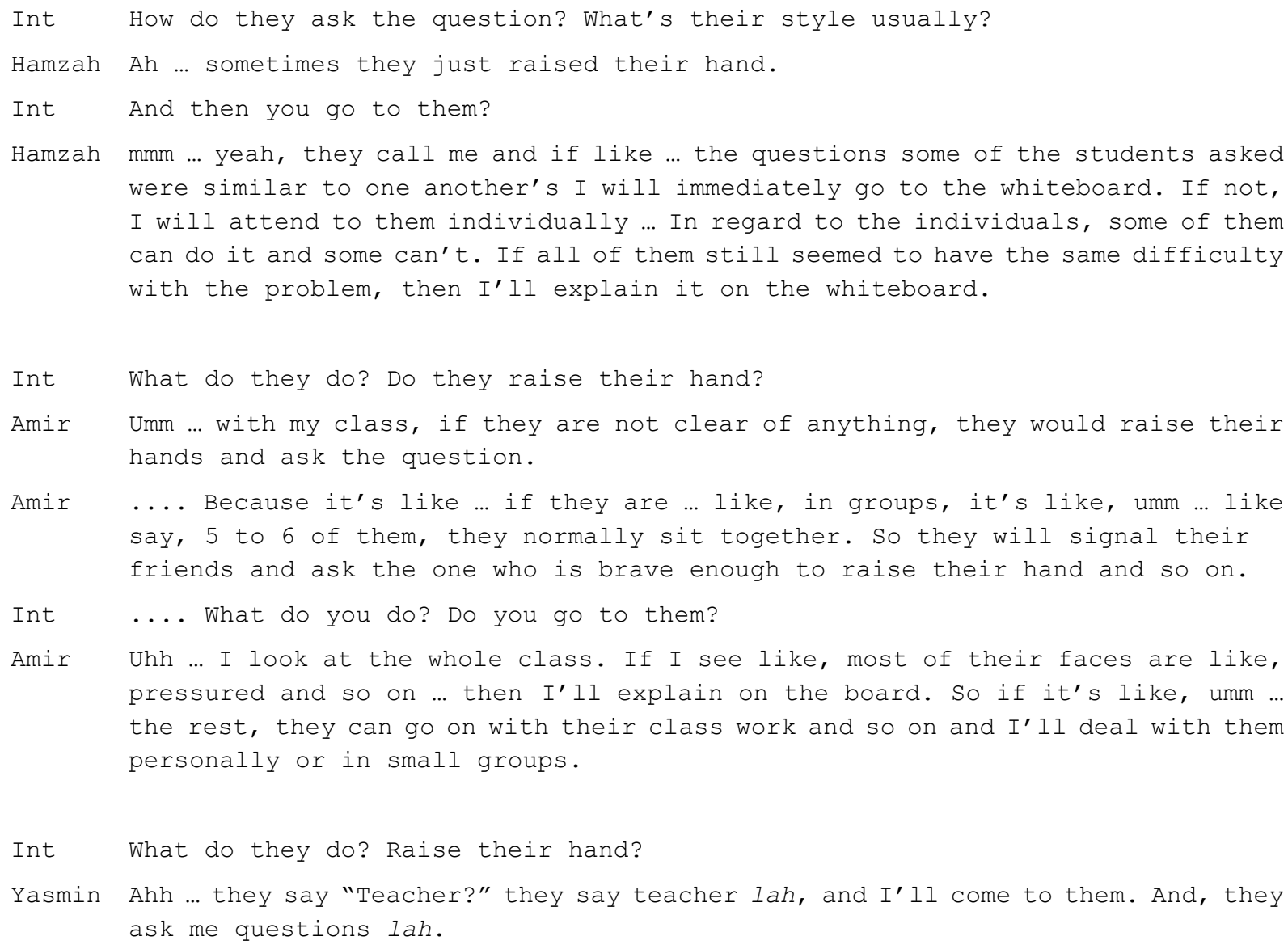




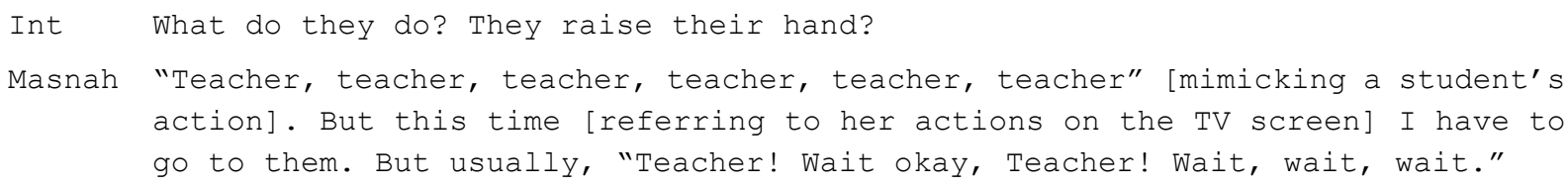

As a matter of fact Masnah illustrated the difference between hers and the students' questioning during the public and private interaction time.

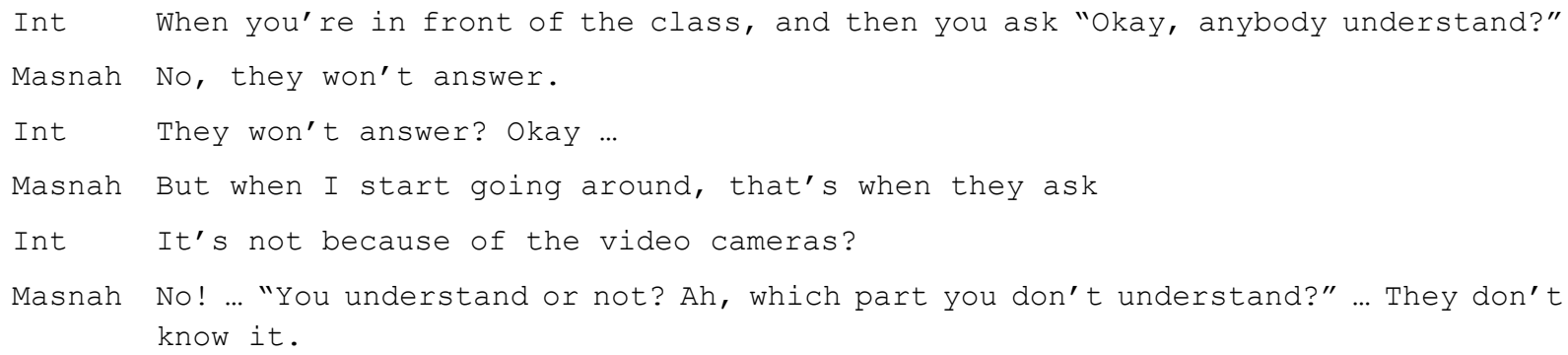

According to Masnah's response, this indicated that her students were more comfortable asking her question(s) when she circulated around the classroom and interacted privately with individual students (that is, the condition of private interaction time), rather than during the time where she was having a dialogue with all her students (public inetraction time). This particular finding supports the third hypothesis given earlier where we stated that students may want to wait until the teacher goes around the classroom to ask him/her a question.

Note that during the interview, only Amir identified a section in his video recorded lesson (that he picked) in which he wished to comment further in regard to his response given above.

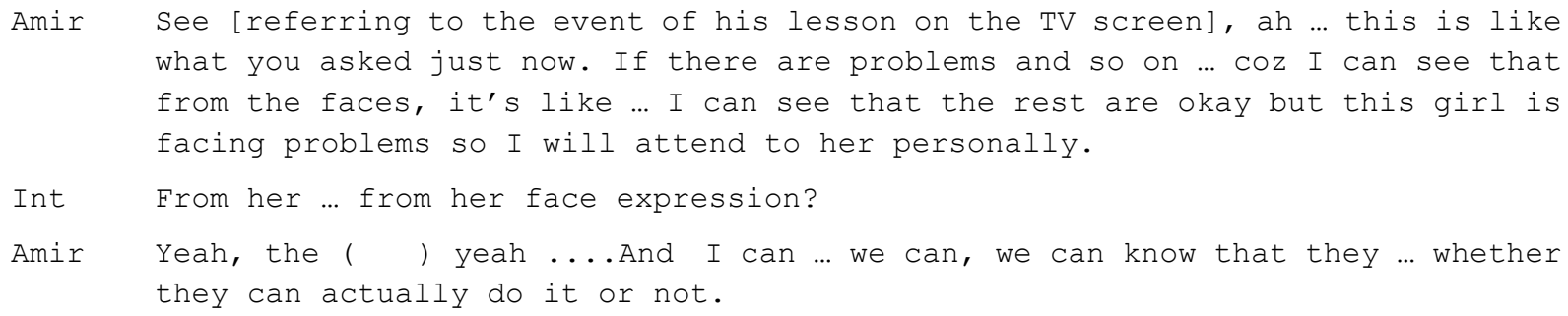

The teachers reported frequent questions from the students, but the students preferred to ask these questions (or were more comfortable asking questions to their teachers) in private conversation moments rather than during public discussion. Moreover, these responses led us to discover that the current occurrence of students' questioning behaviour in their classrooms is common. However, the teachers' perceptions of their students' questioning them seemed to contradict the results of student utterances in the Brunei classrooms we obtained earlier. The results in Table 2 showed that students spoke in very short utterances (one to four words in length) during the public interaction segments of the mathematics lessons (ranged from $92 \%$ to $96 \%$ of $1-4$ word SU in the four Brunei classrooms). All four Brunei teachers stated that their respective students questioned them often in the video recorded lessons; therefore it would be reasonable to say that students must have made several utterances also during the non-public interaction segments. Obviously, asking a mathematics question to a teacher would sometimes take more than four words, thus the results from Table 2 would not give a good indication if we want to portray how often Brunei students spoke or even participate in the classroom (during the entire lesson time).

Another finding worth mentioning here is the teachers' perspective on how the students normally answer their questions in the lessons. The responses given by the teachers (except Hamzah) below were generated from the events in their video recorded lessons that were watched together during the interviews.

For Yasmin, we noticed that, in her video recorded lessons, when she asked questions to her students, she was 
the one who immediately answered it as well. That is, her questions were almost always rhetorical rather than questions to which she expected a student answer. Her comments concerning this are illustrated as follows.

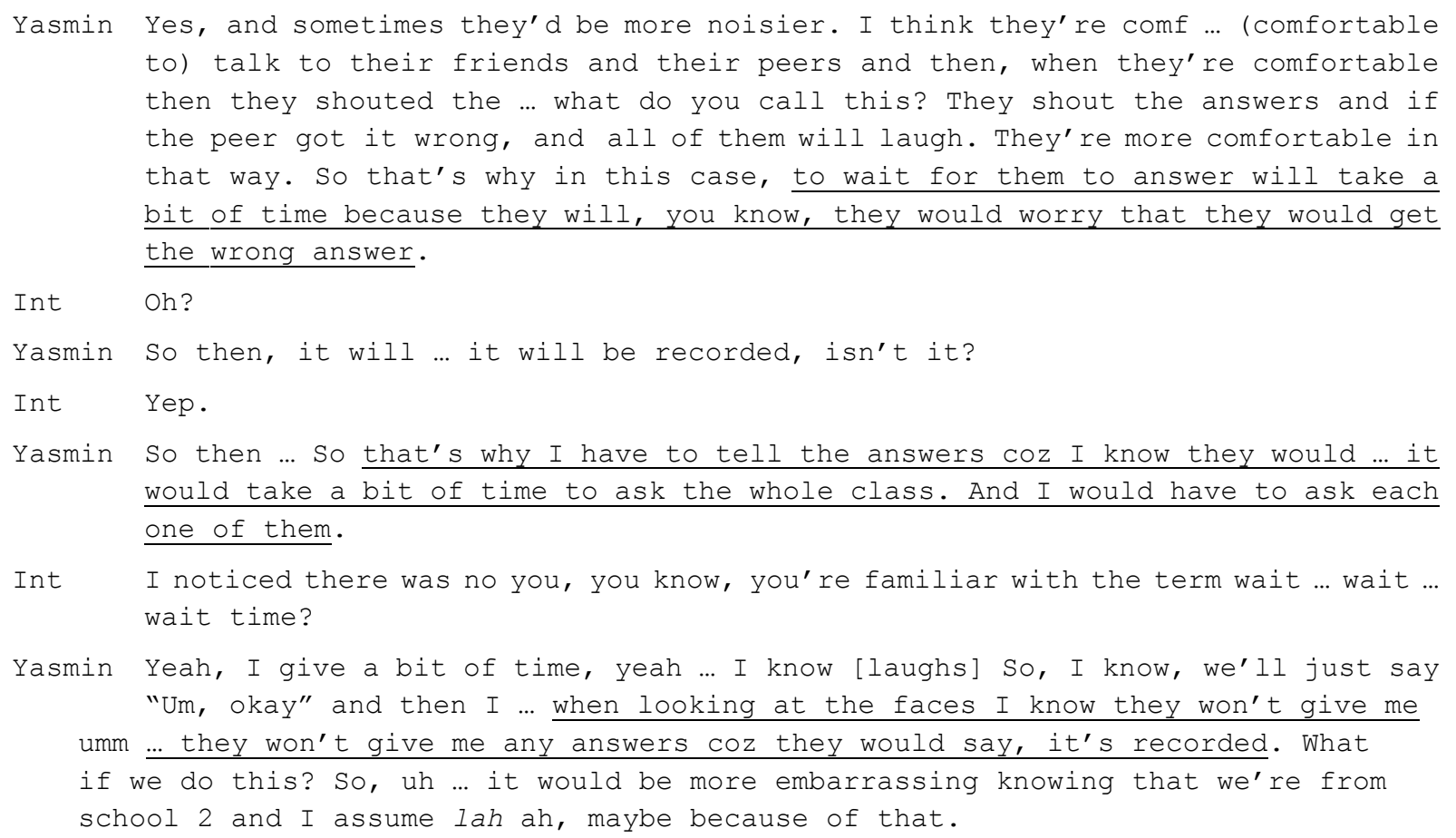

In contrast, when Masnah posed questions to her students, there would be two types of answering behaviour that she will get from her students. Firstly, when the questions were directed to an individual student, the student would not normally give any response at all, and secondly, when the questions sounded like it was directed to all of them, they typically responded in a chorused manner.

Masnah You actually have to force them. "Yeah, after this? Yeah? Then what do you do?" it's always like that. Every single class. But after the class, they'll be very, very hyper.

Int $\quad[$ Laughs $]$

Masnah And then, if I ask them individually, they'll actually ... keep quiet. I've done ... I've been with them since Grade 7, then umm ... if I said "Okay, how do you do this?" They like chorus answers because they said they feel I'm not picking on them specifically ... Yeah, if I said "K, uhh ... Dania, can you do this?" they feel like I'm actually pinpointing them when I asked them individually, actually. They said, "It's like you have something against me. You think I don't know anything."

Masnah .... But, sometimes you know, if the good ones, uhh, they're like, they' re actually happy about it ah. But the ones, the slow ones, you know, I like to ask them, "You understand? You know how to do this?" They don't like it ... It's like they know that ... they are ... that I know that they don't know how to do it. So they feel like I'm trying to pinpoint them, like, they'll just straight away shut up.

Masnah So if I want to ask them individually, I have to ask the good ones. So I ask them, "Which one do you like? Chorus (answer) ... chorus (question) ... chorus answering or you answer yourself?" and they said "chorus answering" and the weak ones would actually shout out the answers together with the ... the rest.

Masnah They like it that way. It's like, happy. They feel happy and everybody's answering ... If I start saying names, they would be like, "Oh God, she's doing 
this again. Pressure, pressure."

According to Masnah, it was not just the video lessons (with cameras present filming her lessons) that was making the students nervous about answering her question, but every single class. Clearly from Masnah's responses she was frustrated with her students' answering behaviour (to her questions), and she would have preferred her students to participate constructively in her lessons rather than responding to her questions in chorused ways. But she was prepared to sacrifice their cognitive engagement in the interest of reducing their stress.

Another related finding concerns with how Amir perceived that it was acceptable his students replied to his questions in chorused ways.

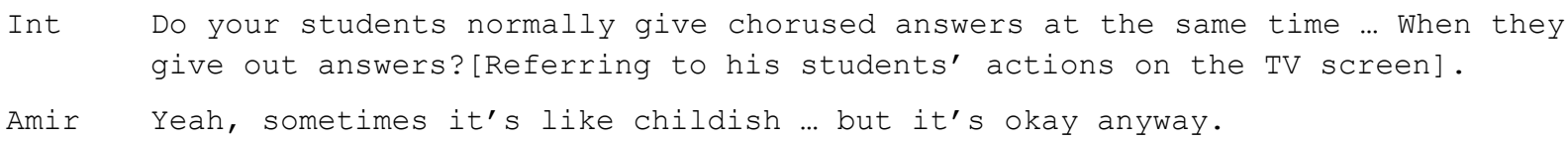

The teacher perceptions on chorused answering by students, given by Amir and Masnah were an interesting addition to our observations. Both teachers were prepared to incorporate chorused answers into their classroom practice, even though both do not really approve. For instance, Hamzah and Yasmin did not mention this issue at all in the interviews, and Amir only talked about it very briefly when the first author questioned him about it (note that during video recording, we noticed that chorused answering happened more frequently in his classroom in comparison to the other classrooms).

\section{Conclusions}

From the first part of the results analyses, we have shown that all four teachers as well as their students spoke in very short utterances during the public interaction segments of the mathematics lessons. In the Brunei classrooms, faster-paced 'back and forth' verbal public exchanges between teachers and students were common. The fast pace of mathematics lesson instruction in the classrooms of the novice teachers was possibly the main reason for these portrayals of classroom activities. But for the experienced teacher (Amir), although he had a relaxed attitude on the instructional delivery of his lesson, he also preferred to firstly, conduct his lesson according to his students' learning pace and secondly, to try to encourage wider student participation. However, in most cases, his actions was sometimes unsuccessful and this led him to persist in repeating his (public) statements several times until he eventually get either a student response or students' responses albeit short choral responses. These actions might have caused him to make short statements similar to the results portrayed as the other three Brunei teachers.

Meanwhile, in the second part of the results analyses, we have reported on the similar emerging issues mentioned by the four teachers from the video-stimulated recall interviews conducted at the end of their video recorded lessons. Teachers' perspectives were elicited by means of their verbal commentaries on the lesson videos and their elaboration on the subsequent interview questions. The similar emerging issues are the prevalence of commonly frequented occurrence of students' questioning behaviour in their classrooms albeit in private conversation moments rather than during the public discussions, and the perceived typicality by two of the teachers in the acceptance of chorused responses by the students. But the issue with chorused answering will only continue to exist when teachers persist in asking their students questions that are of low cognitive level. If these teachers (especially Masnah) were to change the style of their questioning in their lessons to include the "effective questioning techniques" (such as plan relevant questions, phrase questions clearly, ask questions at all levels and so on) suggested by researchers such as Chong and Shahrill (2014), Clarke et al. (2013a), Ellis (1993), Rose and Litcher (1998), Shahrill (2013a, 2013c), Shahrill and Mundia (2014) and Xu et al. (2013), perhaps there would be a change in the nature of the interaction between the teacher and their students. To us, these questioning techniques may be effective if one wants to promote student learning because the list provides the basic dos and don'ts of teacher questioning. Considering the Brunei teachers' concerns in relation to the pace of curriculum to meet the examination deadline, they might say "we don't have time to do this!" or "how can we expect students to respond to our questions if they themselves have to be forced?" Teachers should at least try to incorporate these effective questioning techniques within their instructional teaching tool if they want their students to benefit from their teachings. 


\section{Implications and Recommendations}

In the analysis of the teachers' and students' utterances during the public segments of the mathematics lessons, we found that the students, studied in Brunei, spoke in very short utterances in comparison to their teachers. Given that the overall results pertaining to students' short utterances were consistently high across all four Brunei classrooms (ranged from $92 \%$ to $96 \%$ of one to four words in length), it led us to frame the hypothesis that there might be a lack of students' participation during the mathematics lessons. However, we must remind readers that these results were obtained following the TIMSS-99 Video Study analytical approach (see Hiebert et al., 2003) to study the nature of classroom talk in the lessons only during periods of public interaction. Further investigation of the teachers' interview data, concerning the teachers' perspectives on their students' questioning behaviour, revealed contradictory accounts about the students' participation in the Brunei classrooms. Rather than asking questions or participating in classroom discussions during the public interaction segments, all four teachers indicated that their students preferred to interact with them during the private conversation moments of the lessons. As this was the case, then the results presented earlier, in regard to students' short utterances in the Brunei classrooms during the public segments, might not be an accurate indication of the type or the level of students' participation in the classroom. With more time and resources to be invested in further research, it would be useful to explore further the characteristic features of mathematics classroom talk in Brunei, not just in the public segments but for all classroom interaction segments. The features that we can suggest may be the types of questions asked by the students and/or the teachers. Examining these features as they occur in different interaction segments may help us to better understand what kind of learning opportunities students have as a result of their participation in the classroom.

One of the ways that this study could have been improved would be to interview the students as well. In the LPS project, the students as well as the teachers were involved in the post-lesson video-stimulated interviews. Although this study adapted the LPS style data generation design for this study, our focus was consistently on the four Brunei mathematics teachers. Therefore, we were committed to analysing data pertaining to the teachers only. Furthermore, in this study, we only have the teachers' interview data to draw upon in analysing the teachers' beliefs about questioning. The insights that we have provided specifically concerned teachers. In order to obtain information on how students might benefit from the questioning of the teachers or from questions asked by students, it would be helpful if the students were interviewed as well. By having the students' own views on questioning, perhaps more information could be gathered by comparing and contrasting perceptions from both sides (the learners as well as the instructors of mathematics).

This study has tentatively identified some of the distinctive features of classroom instruction in Brunei, particularly in relation to the length of student utterances. Several avenues for further research are suggested by the findings. In particular, further investigation of student response to the various idiosyncratic instructional practices could contribute to an understanding of their influence on student learning. It is through first recognising distinctive features of local pedagogies and then connecting these to learning outcomes that research is likely to inform teacher education and increase the effectiveness of classroom practice.

\section{References}

Ainley, J. (2007). Using new technologies to investigate and improve learning: Trends and potentials (Keynote address). In A. W. A. Ghani, T. J. Sullivan, H. S. Dhindsa, A. Chamberlain, D. Boorer, K. Wood, \& A. Baimba (Eds.), Changing contours of education: Future trends (pp. 13-24). Gadong: Universiti Brunei Darussalam.

Ang, L. H., \& Shahrill, M. (2014). Identifying students' specific misconceptions in learning probability. International Journal of Probability and Statistics, 3(2), 23-29. http://dx.doi.org/10.5923/j.ijps.20140302.01

Ball, A. F. (2002). Three decades of research on classroom life: Illuminating the classroom communicative lives of America's at-risk students. Review of Research in Education, 26, 71-111. http://dx.doi.org/10.3102/0091732X026001071

Biggs, J. (1994). What are effective schools? Lessons from East and West. The Australian Educational Researcher, 21(1), 19-39. http://dx.doi.org/10.1007/BF03219558

Boaler, J., \& Humphreys, C. (2005). Connecting mathematical ideas: Middle school video cases to support teaching and learning. Portsmouth, NH: Heinemann.

Chong, J. S. Y., \& Shahrill, M. (2014). The refinements needed to improve the teaching of conditional probability. Proceedings of the 2nd International Conference on Social Sciences Research (pp. 389-398). Kota Kinabalu, Sabah, Malaysia: ICSSR 2014, WorldConferences.net. 
Clarke, D. J. (2003). International comparative research in mathematics education. In A. Bishop, K. Clements, C. Keitel, J. Kilpatrick, \& F. Leung (Eds.), Second International Handbook on Mathematics Education (pp. 145-186). Dordrecht, the Netherlands: Kluwer. http://dx.doi.org/10.1007/978-94-010-0273-8_6

Clarke, D. J. (2004). Guest editorial. Researching classroom learning and learning classroom research. The Mathematics Educator, 14(2), 2-6.

Clarke, D. J. (2006a). The LPS research design. In D. J. Clarke, C. Keitel, \& Y. Shimizu (Eds.), Mathematics classrooms in twelve countries: The insider's perspective (pp. 15-36). Rotterdam: Sense Publications.

Clarke, D. J. (2006b). Using international research to contest prevalent oppositional dichotomies. Zentralblattfür Didactik der Mathematik, 38(5), 376-387.http://dx.doi.org/10.1007/BF02652799

Clarke, D. J. (Ed.). (2001). Perspectives on practice and meaning in mathematics and science classrooms. Dordrecht, Netherlands: Kluwer Academic Press.

Clarke, D. J., \& Xu, L. H. (2007). Examining Asian mathematics classrooms through the lens of the distribution of responsibility for knowledge generation. Proceedings of EARCOME4 (the $4^{\text {th }}$ East-Asian Research Conference on Mathematics Education, pp. 518-524), June 18-22, 2007. Penang: University of Malaysia.

Clarke, D. J., \& Xu, L. H. (2008). Distinguishing between mathematics classrooms in Australia, China, Japan, Korea and the USA through the lens of the distribution of responsibility for knowledge generation: Public oral interactivity and mathematical orality. Zentralblattfür Didactik der Mathematik, 40(6), 963-972. http://dx.doi.org/10.1007/s11858-008-0129-5

Clarke, D. J., Emanuelsson, J., Jablonka, E., \& Mok, I. A. C. (2006). The learner's perspective study and international comparisons of classroom practice. In D. J. Clarke, J. Emanuelsson, E. Jablonka, \& I. A. C. Mok (Eds.), Making connections: Comparing mathematics classrooms around the world (pp. 1-22). Rotterdam: Sense Publications.

Clarke, D. J., Keitel, C., \& Shimizu, Y. (2006). The learner's perspective study. In D. J. Clarke, C. Keitel, \& Y. Shimizu (Eds.), Mathematics classrooms in twelve countries: The insider's perspective (pp. 1-14). Rotterdam: Sense Publications.

Clarke, D. J., Mesiti, C., Jablonka, E., \& Shimizu, Y. (2006). Addressing the challenge of legitimate international comparisons: Lesson structure in the USA, Germany and Japan. In D. J. Clarke, J. Emanuelsson, E. Jablonka, \& I. A. C. Mok (Eds.), Making connections: Comparing mathematics classrooms around the world (pp. 23-45). Rotterdam: Sense Publications.

Clarke, D. J., Mesiti, C., O’Keefe, C., Xu, L. H., Jablonka, E., Mok, I. A. C., \& Shimizu, Y. (2007). Addressing the challenge of legitimate international comparisons of classroom practice. International Journal of Educational Research, 46(5), 280-293. http://dx.doi.org/10.1016/j.ijer.2007.10.009

Clarke, D. J., Xu, L., \& Wan, M. E. V. (2013a). Choral response as a significant form of verbal response in mathematics classrooms in seven countries. In A. M. Lindmeier, \& A. Heinze (Eds.), Proceedings of the 37th Conference of the International Group for the Psychology of Mathematics Education (Vol. 2, pp. 201-208). Kiel, Germany: PME.

Clarke, D. J., Xu, L., \& Wan, M. E. V. (2013b). Spoken mathematics as an instructional strategy: The public discourse of mathematics classrooms in different countries. In B. Kaur, G. Anthony, M. Ohtani, \& D. J. Clarke (Eds.), Student Voice in Mathematics Classrooms around the World (pp. 13-32). Rotterdam: Sense Publishers. http://dx.doi.org/10.1007/978-94-6209-350-8_2

Clarke, D. J., Xu, L., \& Wan, M. E. V. (2013c). Students speaking mathematics: Practices and consequences for mathematics classrooms in different countries. In B. Kaur, G. Anthony, M. Ohtani, \& D. J. Clarke (Eds.), Student Voice in Mathematics Classrooms around the World (pp. 33-52). Rotterdam: Sense Publishers. http://dx.doi.org/10.1007/978-94-6209-350-8_3

DuFon, M. A. (2002). Video recording in ethnographic SLA research: Some issues of validity in data collection. Language, Learning and Technology, 6(1), 40-62.

Ellis, K. (1993). Teacher questioning behavior and student learning: What research says to teachers. Paper presented at the Annual Meeting of the Western States Communication Association, Albuquerque, NM.

Fitzgerald, A., Hackling, M., \& Dawson, V. (2013). Through the viewfinder: Reflecting on the collection and analysis of classroom video data. International Journal of Qualitative Methods, 12, 52-64.

Floden, R. E. (2001). Research on effects of teaching: A continuing model for research in teaching. In V. 
Richardson (Ed.), Handbook of Research on Teaching (4th ed., pp. 3-16). Washington, DC: American Education Research Association.

Franke, M. L., Kazemi, E., \& Battey, D. (2007). Mathematics teaching and classroom practice. In F. K. Lester (Ed.), Second handbook of research on mathematics teaching and learning: A project of the national council of teachers of mathematics (pp. 225-256). Charlotte, NC: Information Age.

Go, B. T., \& Shahrill, M. (2014). Investigating students' learning of function notation. Proceedings of the 2nd International Conference on Social Sciences Research (pp. 399-408). Kota Kinabalu, Sabah, Malaysia: ICSSR 2014, WorldConferences.net.

Goos, M., Stillman, G., \& Vale, C. (2007). Teaching secondary school mathematics: Research and practice for the $21^{\text {st }}$ century. Crows Nest, New South Wales: Allen \&Unwin.

Haq, F. S., \& Mundia, L. (2012). Comparison of Brunei pre-service student teachers' attitudes to inclusive education and specific disabilities: Implications for teacher education. Journal of Educational Research, 105(5), 366-374. http://dx.doi.org/10.1080/00220671.2011.627399

Hiebert, J., \& Grouws, D. A. (2007). The effects of classroom mathematics teaching on students' learning. In F. K. Lester (Ed.), Second handbook of research on mathematics teaching and learning: A project of the national council of teachers of mathematics (pp. 371-404). Charlotte, NC: Information Age.

Hiebert, J., Gallimore, R., Garnier, H., Givvin, K. B., Hollingsworth, H., Jacobs, J., . . Stigler, J. (2003). Teaching mathematics in seven countries: Results from the TIMSS 1999 Video Study. Washington, DC: U.S. Department of Education, National Center for Education Statistics.

Jaidin, J. H. (2009). Conceptions of learning held by upper primary children in government schools in Brunei Darussalam (Unpublished doctoral dissertation). Queensland University of Technology, Brisbance, Australia.

Jawawi, R. (2009). Conceptions of economics pre-services teacher's use of subject knowledge in teaching, economics and commerce at secondary schools in Brunei Darussalam (Unpublished doctoral dissertation). University of London, London, United Kingdom.

Jawawi, R. (2010). Reflective practice in teaching economics and commerce: A case study of pre-service teachers in Brunei Darussalam. Saarbrücken, Germany: VDM Verlag Dr. Müller.

Kawanaka, T., \& Stigler, J. W. (1999). Teachers' use of questions in eighth-grademathematics classrooms in Germany, Japan, and the United States. Mathematical Thinkingand Learning, 1(4), 255-278. http://dx.doi.org/10.1207/s15327833mt10104_1

Khoo, S. C. (2001). The teaching and learning of geometry (Unpublished master dissertation). Universiti Brunei Darussalam, Brunei Darussalam.

Koizumi, Y. (2013). Similarities and differences in teachers' questioning in German and Japanese mathematics classrooms. ZDM The International Journal on Mathematics Education, 45, 47-59. http://dx.doi.org/10.1007/s11858-012-0482-2

Leung, F. K. S. (1995). The mathematics classroom in Beijing, Hong Kong and London. Educational Studies in Mathematics, 29(4), 297-325. http://dx.doi.org/10.1007/BF01273909

Leung, F. K. S. (2001). In search of an East Asian identity in mathematics education. Educational Studies in Mathematics, 47(1), 35-51. http://dx.doi.org/10.1023/A:1017936429620

Leung, F. K. S. (2002). Behind the high achievement of East Asian students. Educational Research and Evaluation, 8(1), 87-108. http://dx.doi.org/10.1076/edre.8.1.87.6920

Leung, F. K. S. (2005). Some characteristics of East Asian mathematics classrooms based on data from the TIMSS 1999 Video Study. Educational Studies in Mathematics, 60(2), 199-215. http://dx.doi.org/10.1007/s10649-005-3835-8

Leung, F. K. S. (2006). Mathematics education in East Asia and the West: Does culture matter? In F. K. S. Leung, K.-D. Graf, \& F. J. Lopez-Real (Eds.), Mathematics education in different cultural traditions-A comparative study of East Asia and the West: The $13^{\text {th }}$ ICMI study (pp. 21-46). New York: Springer. http://dx.doi.org/10.1007/0-387-29723-5

Leung, F. K. S. (2008a). The significance of IEA studies for education in East Asia and beyond. PowerPoint presentation of a plenary keynote speech at the $3^{\text {rd }}$ IEA International Research Conference (IRC-2008), 
Taipei, Chinese Taipei, September 18-20, 2008.

Leung, F. K. S. (2008b). In the books there are golden houses: Mathematics assessment in East Asia. Zentralblattfür Didactik der Mathematik, 40(6), 983-992. http://dx.doi.org/10.1007/s11858-008-0157-1

Lim, C. S. (2007). Characteristics of mathematics teaching in Shanghai, China: Through the lens of a Malaysian. Mathematics Education Research Journal, 19(1), 77-89. http://dx.doi.org/10.1007/BF03217450

Lim, T. H. (2000). The teaching and learning of algebraic equations and factorisation in O-level mathematics: A case study (Unpublished master dissertation). Universiti Brunei Darussalam, Brunei Darussalam.

Mundia, L. (2007). Early childhood education in Swaziland and Brunei Darussalam: Goals, achievements and challenges. Early Child Development and Care, 177(2), 151-158. http://dx.doi.org/10.1080/03004430500375885

Mundia, L. (2009). Implementation of inclusive education in Brunei Darussalam: Review of possible implications on school counsellors. Electronic Journal for Inclusive Education, 2(4). Spring/Summer Issue. Retrieved from http://www.cehs.wright.edu/ prenick/Spring_Summer09_Edition/spr_sum09.html

Mundia, L. (2010a). Problems in learning mathematics: Comparison of Brunei junior high school students in classes with and without repeaters. Journal of Mathematics Research, 2(3), 150-160. http://dx.doi.org/10.5539/jmr.v2n3p150

Mundia, L. (2010b). Implementation of SPN21 curriculum in Brunei Darussalam: A review of selected implications on school assessment reforms. International Education Studies, 3(2), 119-129. http://dx.doi.org/10.5539/ies.v3n2p119

Mundia, L. (2012a). Policy changes in Brunei teacher education: Implications for the selection of trainee teachers. The Education Forum, 76(3), 326-342. http://dx.doi.org/10.1080/00131725.2012.682489

Mundia, L. (2012b). The Assessment of Mathematics Learning Difficulties in a Primary Grade 4 Child with High Support Needs: Mixed Methods Approach. International Electronic Journal of Elementary Education, 4(2), 347-366. http://dx.doi.org/10.1080/00131725.2012.682489

Niss, M. (2007). Reflections on the state of and trends in research on mathematics teaching and learning: From here to Utopia. In F. K. Lester (Ed.), Second handbook of research on mathematics teaching and learning: A project of the National Council of Teachers of Mathematics (pp. 1293-1312). Charlotte, NC: Information Age.

Nor, H. N. H. M., \& Shahrill, M. (2014). Incorporating the use of poster and oral presentations as an alternative assessment in the teaching of secondary mathematics. Proceedings of the 2 nd International Conference on Social Sciences Research (pp. 369-378). Kota Kinabalu, Sabah, Malaysia: ICSSR 2014, WorldConferences.net.

Omar, N. A., Matarsat, S. R., Azmin, N. H., Wei, V. C. A., Nasir, M. M. M., Sahari, U. K. S., Shahrill, M., \& Mundia, L. (2014). The Ideal Psychology Teacher: Qualitative Analysis of Views from Brunei GCE A-Level Students and Trainee Psychology Teachers. Asian Social Science, 10(12), 184-194. http://dx.doi.org/10.5539/ass.v10n12p184

Park, K., \& Leung, F. K. S. (2006). Mathematics lessons in Korea: Teaching with systematic variation. In D. J. Clarke, C. Keitel, \& Y. Shimizu (Eds.), Mathematics classrooms in twelve countries: The insider's perspective (pp. 247-261). Rotterdam: Sense Publications.

Philipp, R. A. (2007). Mathematics teachers' beliefs and affect. In F. K. Lester (Ed.), Second handbook of research on mathematics teaching and learning: A project of the national council of teachers of mathematics (pp. 257-315). Charlotte, NC: Information Age.

Remedios, L., Clarke, D., \& Hawthorne, L. (2008). Framing Collaborative Behaviors: Listening and Speaking in Problem-based Learning. The Interdisciplinary Journal of Problem-based Learning, 2(1), 1-20. http://dx.doi.org/10.7771/1541-5015.1050

Rose, S., \& Litcher, J. (1998). Effective questioning techniques: In theory and practice. In L. P. McCoy (Ed.), Studies in Teaching 1998 Research Digest (Research projects presented at Annual Research Forum (pp. 106-110)). Wake Forest University, Winston- Salem, NC.

Salam, N. H. A. (2011). A case study on classroom interaction in three secondary mathematics classrooms (Unpublished master dissertation). Universiti Brunei Darussalam, Brunei Darussalam. 
Salam, N. H. A., \& Shahrill, M. (2014). Examining classroom interactions in secondary mathematics classrooms in Brunei Darussalam. Asian Social Science, 10(11), 92-103. http://dx.doi.org/10.5539/ass.v10n11p92

Sarwadi, H. R. H., \& Shahrill, M. (2014). Understanding students' mathematical errors and misconceptions: The case of year 11 repeating students. Mathematics Education Trends and Research, 1-10. http://dx.doi.org/10.5899/2014/metr-00051

Sfard, A. (2005). What could be more practical than good research? On mutual relations between research and practice on mathematics education. Educational Studies in Mathematics, 58(3), 393-413. http://dx.doi.org/10.1007/s10649-005-4818-5

Shahrill, M. (2005). A further investigation of decimal misconceptions held by primary and secondary students (Unpublished master dissertation). University of Melbourne, Melbourne, Australia.

Shahrill, M. (2009). From the general to the particular: Connecting international classroom research to four classrooms in Brunei Darussalam (Unpublished doctoral dissertation). University of Melbourne, Melbourne, Australia.

Shahrill, M. (2011). Investigating decimals misconceptions: Cross-sectional and longitudinal approaches. Saarbrücken, Germany: VDM Verlag Dr. Müller.

Shahrill, M. (2013a). Review of teacher questioning in mathematics classrooms. International Journal of Humanities and Social Science, 3(17), 224-231.

Shahrill, M. (2013b). Clustering of decimal misconceptions in primary and secondary classes. International Journal of Humanities and Social Science, 3(11), 58-65.

Shahrill, M. (2013c). Comparing teacher questioning in American and Australian mathematics classrooms. Journal of Applied Research in Education, 17, 26-40.

Shahrill, M., \& Mundia, L. (2014). The use of low-order and higher-order questions in mathematics teaching: Video analyses case study. Journal of Studies in Education, 4(2), 15-34. http://dx.doi.org/10.5296/jse.v4i2.5318

Shahrill, M., Mahalle, S., Matzin, R., Hamid, M. H. S., \& Mundia, L. (2013). A Comparison of Learning Styles and Study Strategies used by Low and High Math Achieving Brunei Secondary School Students: Implications for Teaching. International Education Studies, 6(10), 39-46. http://dx.doi.org/10.5539/ies.v6n10p39

Tait, K., \& Mundia, L. (2014). A Comparison of Brunei and Hong Kong-SAR Student Teachers' Self-efficacy in Implementing Inclusive Education Practices: Implications for Teacher Education. Asian Social Science, 10(1), 51-60. http://dx.doi.org/10.5539/ass.v10n1p51

Tait, K., \& Mundia, L. (2012). Preparing teachers to meet the challenges of inclusive education in Negara Brunei Darussalam. In C. I. Forlin (Ed.), Future directions for inclusive teacher education: An international perspective (pp. 60-69). Hong Kong: Routledge/Francis \& Taylor.

Xu, L., Wan, M. E. V., \& Clarke, D. J. (2013). Discourse patterns employing choral response in mathematics classrooms in seven countries. In A. M. Lindmeier, \& A. Heinze (Eds.), Proceedings of the 37th Conference of the International Group for the Psychology of Mathematics Education (Vol. 5, p. 196). Kiel, Germany: PME.

Zhang, D. Z., Wong, N. Y., \& Leung, F. K. S. (1998). Some characteristics of mathematics education in East Asia: An overview from China. Proceedings of the ICMI-EARCOME 1 (the $1^{\text {st }}$ ICMI East Asia Regional Conference on Mathematics Education, pp. 49-68), August 17-21, 1998. Republic of Korea: Korea National University of Education.

\section{Note}

Note 1. The average number of teacher words per lesson in Hong Kong and Japan were 5798 and 5148 respectively (because lesson duration varies across the countries, the comparison of teacher and student public talk was standardised for 50 minutes of lesson time). The average number of teacher words across six of the TIMSS-countries was 5533 words (Hiebert et al., 2003; Leung, 2005, 2008a). Meanwhile, the average number of student words per lesson in Hong Kong and Japan were 640 and 766 respectively, compared with an average of 846 words across six of the TIMSS-countries (Hiebert et al., 2003; Leung, 2005, 2008a). 


\section{Copyrights}

Copyright for this article is retained by the author(s), with first publication rights granted to the journal.

This is an open-access article distributed under the terms and conditions of the Creative Commons Attribution license (http://creativecommons.org/licenses/by/3.0/). 